Open Access

\title{
How does the servant supervisor influence the employability of postgraduates? Exploring the mechanisms of self-efficacy and academic engagement
}

\author{
Lifeng Zhong ${ }^{1}$, Zhichao Qian ${ }^{1 *}$ and Dongdong Wang ${ }^{2}$
}

\author{
* Correspondence: \\ qianzhichao2014@163.com \\ 'Business School, Renmin University \\ of China, Beijing 100872, China \\ Full list of author information is \\ available at the end of the article
}

\begin{abstract}
Drawing on the conservation of resource theory, this study investigates the mediating effects of self-efficacy and academic engagement in the relationship between servant supervision and postgraduates' employability. We conducted a field study with 598 postgraduates (students for the research-based master's degree and $\mathrm{PhD}$ candidates) enrolled in universities in China to test our hypotheses. We developed and tested a model contending that servant supervisors propagate servant supervision among postgraduates through postgraduates' self-efficacy and academic engagement, which indirectly influences postgraduates' employability. The results support the mediating effects of both self-efficacy and academic engagement on the relationship between servant supervision and postgraduates' employability. Finally, the theoretical and practical implications are discussed.
\end{abstract}

Keywords: Servant supervision, Self-efficacy, Academic engagement, Employability, Conservation of resource theory, Postgraduates, Leadership

\section{Introduction}

Servant leadership in management gave rise to an abundance of research in recent years, focusing particularly on the workplace, such as companies, restaurants, stores, hospitality and tourism industries (Chiniara and Bentein 2016; Hunter et al. 2013; Liden et al. 2014; Neubert et al. 2016; Zou et al. 2015). Greenleaf (1970) describes servant leadership as "natural feeling that one wants to serve, to serve first" (p.14), then aspires to lead. Greenleaf (1970) construes servant leadership as an other-oriented approach that emphasizes serving others, sharing power, promoting followers' progress and building a sense of community both within the work group and outside the walls of the organization. The positive influences of servant leadership in organizations have been highlighted, and include, but are not limited to job performance, customer service performance, organizational citizenship behavior (OCB), creativity and family-work balance (Chiniara and Bentein 2018; Liden et al. 2014; Wang et al. 2017; Yang et al. 2017; Yang et al. 2018). However, as a management phenomenon, the existing literature on

(c) The Author(s). 2020 Open Access This article is licensed under a Creative Commons Attribution 4.0 International License, which permits use, sharing, adaptation, distribution and reproduction in any medium or format, as long as you give appropriate credit to the original author(s) and the source, provide a link to the Creative Commons licence, and indicate if changes were made. The images or other third party material in this article are included in the article's Creative Commons licence, unless indicated otherwise in a credit line to the material. If material is not included in the article's Creative Commons licence and your intended use is not permitted by statutory regulation or exceeds the permitted use, you will need to obtain permission directly from the copyright holder. To view a copy of this licence, visit http://creativecommons.org/licenses/by/4.0/. 
servant leadership and its mechanism is limited to the workplace. Few studies of servant leadership has been conducted in the university context, where the relationship between postgraduate students and their supervisors is particularly pertinent. During the educational process, the guidance from a supervisor to postgraduate students is not only a one-way guidance relationship, but also a mutual influence relationship, which stems from the dual role of the supervisor as a "reviewer" and a "guider" (Wubbels et al. 2006). The relationship between a supervisor and postgraduate students is a kind of internal influence relationship that lasts for a lifetime once it is established. Therefore, the quality of the relationship between a supervisor and postgraduate students has a far-reaching impact. In view of this, the level of a supervisor and the style of leadership applied by the supervisor have a vital influence on a postgraduate student's academic achievement, physical and mental health, and future development. The servant leader is a servant and a steward, rather than a leader or owner (Greenleaf 1970). If the supervisor adopts servant guidance behavior, this may become the main source of positive psychological reaction, resulting in postgraduate students finding it easier to conduct their research. The service-oriented supervisor focuses on postgraduates, values their individual needs, strengthens their abilities, and emphasizes the quality of the supervisor-postgraduate relationship. As such, research is necessary to understand a supervisor's service-oriented supervision and his or her influence on the postgraduates' employability.

This study contextualizes servant supervision in the field of education (universities) and investigates how it influences postgraduates' employability. The aim of this research is to examine how (the mechanism) servant supervision influences postgraduates' employability through self-cognition and motivation. Here, we draw on the conservation of resource theory (Hobfoll 1989) to develop and test the relationship between servant supervision and postgraduates' employability mediated by self-efficacy and academic engagement.

Our study has both theoretical and practical importance. From a theoretical perspective, it contributes to the literature on servant supervision and employability in important and meaningful ways. First, we investigate whether servant supervision can serve as an important predictor of postgraduates' employability. Although employability has been increasingly recognized as a vital resource in a university setting (e.g., Forrire et al. 2015), surprisingly, no prior work has empirically investigated employability through the supervisor servant lens. Hence, our study is the first to consider servant supervision as an important antecedent of employability. Second, through the integrated conservation of resource theory and self-determination theory, we identify postgraduates' self-efficacy and academic engagement as two distinct pathways through which servant supervision is associated with postgraduates' employability. Interconnecting the intervening roles of the service-oriented supervisor, this study advances theories by delineating the roles of different regulatory mechanisms in servant supervision. Moreover, whereas the majority of past studies on employability have adopted the career management perceptive to guide their research at the macro and firm levels (e.g., Forrier et al. 2015; Lysova et al. 2018; Nelissen et al. 2017; van der Heijde and van der Heijden 2006), this study adopts a supervisor's perspective to consider employability as an individual ability and resource, and examines servant supervision as a predictive variable of employability. From a practical perspective, our study highlights the important role that supervisors play in postgraduates' employability in universities. Among the numerous social relations, the relationship between postgraduate students and supervisors in universities has certain specificity. Firstly, it is a lifelong 
mentoring relationship once established, which is different from the ordinary teacher-student relationship. Therefore, the quality of the relationship between postgraduate students and supervisors during the school period has a far-reaching impact. Secondly, postgraduate students finish relatively high-level research work under the guidance of their supervisors. The level of supervisors and the relationship with their students will have an important impact on students' academic performance, physical and mental health, and even their career choices after graduation. In recent years, the irrational behavior of university postgraduates under high pressure has been increasing, which will have a negative impact on the students themselves and the university as a whole. In view of this, if the supervisor assumes a service-oriented supervision role, he or she will likely become a major source of spiritual support for the postgraduate students, which can reverberate with students to result in positive attitudes to their work. Therefore, academic circles should pay more attention to supervision on postgraduate students and create a pleasant environment for postgraduates' study and life.

\section{Theoretical background and hypothesis development \\ Servant supervision and employability \\ Servant supervision}

Servant leadership is based on the premise that leaders who are best able to motivate followers are those who focus least on satisfying their own personal needs and most on prioritizing the fulfillment of the needs of their followers (Greenleaf 1970). "The servant-leader is servant-leader first" (Greenleaf 1970: p. 13). Leaders invest time and energy to listen to and understand their followers' needs, desires, goals, and abilities, and seek to provide the best for their followers. With reference to servant leadership, there is no other leadership theory that pays as much attention to the needs of followers as this (Mayer 2010). The characteristics of servant leadership can be summarized from two perspectives: One is caring for the followers' interests, which goes beyond the self-interest trait of servant leadership; the other is the ultimate goal of servant leadership which is not only to achieve the goals of the organization, but also to consider the benefits of other stakeholders and communities.

Servant leadership has been put forward as a multidimensional construct (Barbuto Jr and Wheeler 2006; Ehrhart 2004; Liden et al. 2008; van Dierendonck and Nuijten 2011). The dimensions put forward by Liden et al. (2008) are: (1) emotional healing, which involves the degree to which the leader cares about the followers' personal problems and well-being; (2) creating value for the community, which captures the leader's involvement in helping the community surrounding the organization as well as encouraging followers to be active in the community; (3) conceptual skills, reflecting the leader's competency in solving work problems and understanding the organization's goals; (4) empowering, assessing the degree to which the leader entrusts his or her followers with responsibility, autonomy, and decision-making influence; (5) helping subordinates grow and succeed, capturing the extent to which the leader helps his or her followers reach their full potential and succeed in their careers; (6) putting subordinates first, assessing the degree to which the leader prioritizes meeting the needs of his or her followers before tending to his or her own needs; and (7) behaving ethically, which includes being honest, trustworthy, and serving as a model of integrity. 
Previous research findings support the relationship between servant leadership and important outcomes such as job satisfaction (Schneider and George 2011). While a substantial amount of the initial servant leadership research focuses on construct development (Barbuto Jr and Wheeler 2006; Dennis and Bocarnea 2005; Ehrhart 2004; Liden et al. 2008; Sendjaya et al. 2008; van Dierendonck and Nuijten 2011), recent research continues to grow in scope and is a demonstration of its practical utility to organizations (e.g., Hunter et al. 2013; Liden et al. 2014; Peterson et al. 2012). Servant leadership contributes positively to the satisfaction, creativity, engagement, disengagement, and turnover intention of employees (Hunter et al. 2013; Liden et al. 2014; Mayer 2010; Neubert et al. 2008; Neubert et al. 2016), as well as their helping behavior (Neubert et al. 2016; Zou et al. 2015), employee performance (task and in-role performance) and commitment (Chiniara and Bentein 2016, 2018; Liden et al. 2008; Liden et al. 2014; Schwarz et al. 2016), the quality of employee family life (Zhang et al. 2012), OCB that benefits employees and the organization (Chiniara and Bentein 2016, 2018; Hunter et al. 2013; Neubert et al. 2008; Walumbwa et al. 2010), citizenship that benefits the community (Liden et al. 2008), team innovation and performance (Hu and Liden 2011; Schaubroeck et al. 2011; Yoshida et al. 2014), organizational performance (Liden et al. 2014; Peterson et al. 2012), and customer satisfaction (Chen et al. 2015; Liden et al. 2014).

\section{Employability}

Employability is originally conceived of important to graduates, and to make the labor market more inclusive for vulnerable groups (Forrier et al. 2015). Jobseekers might also be expected to aspire to some level of continuous employment to establish a career following the acquisition of a degree.

Due to differences in research perspectives, the structural dimensions and measurement tools of employability are diverse. For example, several scholars have claimed that employability is a set of abilities that enable individuals to acquire and maintain a job (i.e., competence-based employability) (van der Heijde and van der Heijden 2006). In turn, others have focused on employability as the self-perception of individuals regarding their competence to gain and retain employment (i.e., perceived employability) (Vanhercke et al. 2014). At present, one dimension (Berntson and Marklund 2007), two dimensions (Forrier and Sels 2003; Rothwell and Arnold 2007), four dimensions (Fugate et al. 2004) and five dimensions (van der Heijde and van der Heijden 2006) of employability have been recognized.

Previous studies have suggested that employability is a multi-faceted construct (Forrier and Sels 2003) with both internal and external dimensions (Kirschenbaum and ManoNegrin 1999; Rajan 1997; Rothwell and Arnold 2007). Internal factors for job hunters include vocational or job-related knowledge and skills, and mastery of job search techniques (Hillage and Pollard 1998). External factors for job hunters include such aspects as demand for workers in different occupations (Hillage and Pollard 1998). Fugate et al. (2004) argue that employability is a "psychological construct that embodies individual characteristics that...enhance the individual-work interface" (p. 15).

Recent research on the predictors of employability has focused on skill development, individual traits and environment traits, such as proactive orientation, interpersonal rejection sensitivity and career goal-performance discrepancy (Creed et al. 2017), academic performance combined with the participation in extracurricular activities (Pinto and Ramalheira 2017), 
proactive professional development and career inflexibility (Lysova et al. 2018), as well as work-related flow (van der Heijden and Bakker 2011). Moreover, formal on-the-job training, upward job transition and skill utilization affect perceived internal employability, while career advancement also affects perceived external employability (Nelissen et al. 2017). Numerous researchers have distinguished between internal and external employability (Nelissen et al. 2017) and empirical results reveal that internal employability is positively related to loyalty and voice behavior; while in contrast, external employability mediates turnover intention (Nelissen et al. 2017). The relationship between employability and turnover intention has been analyzed in several studies, and researchers have pointed out that employability related to turnover intention depends on different extent conditions such as job control (de Cuyper et al. 2011), affective commitment or job security (Acikgoz et al. 2016), and perceived career opportunity (Lu et al. 2016). In this research, we accept the ability concept and refer to employability as a set of abilities that enable individuals to acquire and maintain a job (van der Heijde and van der Heijden 2006). While the previous literature can contribute to our understanding of when and why employability occurs at the firm-level, we believe that adopting a leadership lens to examine the antecedent of employability can further advance career management research because employability is relevant to one's career prospects (Acikgoz et al. 2016; Nelissen et al. 2017). In the following sections, we analyze why employability can be explained from servant supervision behavior in the workplace and how servant supervision can shape the postgraduates' employability.

This study uses the conservation of resource (COR) theory as a potential explanation for the impact of servant supervision on employability. The COR proposes that people attach importance to various resources: material objects, conditions, personal characteristics, and energies (Hobfoll 1989, 2001). People try to acquire and maintain resources to reduce stress, and after acquiring resources, they will use these resources to obtain more resources (Hobfoll 1989). Based on this assumption, the theory develops two basic principles. One is the principle of resource loss priority, that is, the feelings caused by resource loss and resource acquisition are asymmetric, which means that compared with resource acquisition, individuals are more sensitive to resource loss. The second is the principle of resource investment, which states that individuals must constantly invest in existing resources for the purpose of protecting their own resources to recover rapidly from resource depletion or obtain new resources (Brummelhuis and Trougakos 2014; Hobfoll 2001). As far as this study is concerned, it is clear that when individuals acquire existing resources, they will first protect the resources they have and then seek to obtain more resources through the existing resources. Based on this perspective, employability is a condition that can be conceived as a personal resource (Kirves et al. 2014). Accordingly, the COR theory suggests that as a personal resource, employability may help individuals leave their current jobs with the expectation of better employment conditions elsewhere in an effort to increase their overall resources. Moreover, from the notion of variables, servant supervision emphasizes listening, empathy, stewardship, and awareness. It creates a pervasive social context that positively affects the skills and knowledge obtained by postgraduates. For the majority of postgraduates, studying at university can help them obtain more skills and knowledge and prepare for employment. In respect to employment, employability appears as a significant ability for students (McArdle et al. 2007). During the period when postgraduates are studying, service-oriented supervision focuses more on their growth and provides 
situational cues from which they interpret and establish their goals and objectives in the academic field, thereby enhancing their abilities and capital, including their employability. On the basis of this reasoning, we propose the following hypothesis.

Hypothesis 1 Servant supervision is positively related to postgraduates' employability.

\section{Servant supervision, self-efficacy and academic engagement Self-efficacy}

Bandura's theory states that self-efficacy refers to "beliefs in one's capabilities to organize and execute the courses of action required producing given attainments" (Bandura 1997: p. 3). People with a low sense of self-efficacy are associated with depression, anxiety, and helplessness (Bandura 1997). By contrast, people who have a high sense of self-efficacy tend to regard themselves as being in a successful situation, which then becomes a positive driving force for their performance (Chemers et al. 2001). People with high self-efficacy tend to make numerous efforts to overcome their difficulties, and even when they face problems, they usually treat these as a challenge rather than an obstacle (Wang et al. 2019). Moreover, they often choose to undertake considerably challenging tasks, set high goals, and remain on task for the long term (Chemers et al. 2001).

Studies have shown that the presence of servant leaders can positively predict selfefficacy over several years. In support of this view, Chen and Bliese (2002) have found that leadership plays an important role in enhancing self-efficacy because leaders help clarify roles and provide social support for their employees. Moreover, Walumbwa et al. (2010) have demonstrated that self-efficacy as a mediator accounts for the relationship between service leadership and OCB. Within the educational domain, the servant supervisor develops postgraduates' self-efficacy by enhancing their academic competence and abilities. The servant supervisor also provides students with the knowledge necessary to identify successful solutions to academic problems and improve the abilities of their students. Moreover, the servant supervisor first considers postgraduates' personal development by recognizing their existing knowledge, skills, needs, goals, and abilities, and then provides opportunities for them to develop new skills and help achieve their career goals. By increasing self-efficacy, such supervisors are more likely to enable their postgraduates to be successful by developing and improving their entire range of competences, knowledge, and abilities.

Based on the COR theory, this study interprets stress and exhaustion from the perspective of resource losses and gains, that is, people always try to acquire, retain and maintain the resources they value, which may be related to material things, work control and decision-making power, work autonomy, return, reward, time and so on. Alternatively, the resources may be related to personality, such as self-efficacy and self-esteem. These resources are scarce, but through them, people can obtain other valuable resources to meet their needs, thus producing positive results (Hobfoll 1989, 2001). When students receive servant supervision, their self-efficacy is improved, which makes them more confident about obtaining further resources. Thus, we expect postgraduates' self-efficacy to mediate the relationship between servant supervision and employability. However, because we argue later that the influence of servant supervision on employability may also be affected by other mediators, such as academic engagement with the employability, we propose the following hypothesis. 
Hypothesis 2 Postgraduates' self-efficacy partially mediates the relationship between servant supervision and employability.

\section{Academic engagement}

Academic engagement is a multidimensional construct that addresses students' psychosocial investment and involvement in academic activities (Appleton et al. 2008; Lee and Shute 2010; Skinner et al. 2009). Although a consensus regarding the number of distinct facets that compose academic engagement has yet to be reached, it is generally agreed that engagement as a positive individual trait requires the coordination of behaviors, emotions, and cognition (Appleton et al. 2008; Fredricks et al. 2004). In this research, we investigate academic engagement in two dimensions: behavioral and emotional engagement. Behavioral engagement refers to the extent to which students actively engage in specific academic tasks (Meyer and Turner 2002; Skinner et al. 2009). Emotional engagement pertains to the degree to which students experience positive impacts when participating in academic activities (Meyer and Turner 2002; Skinner et al. 2009). Academic engagement is considered an essential element in the success of students' learning experiences (Skinner et al. 2008).

High levels of academic engagement can lead to desirable outcomes, which is an important condition for performance and persistence in educational tasks and institutions (Fredricks et al. 2004). The behavioral dimension of engagement, generally speaking, means that students make an effort, concentrate and remain actively engaged in their academic activities. Meanwhile, for the emotional dimension of engagement, students focus on learning activities with enthusiasm, interest, and enjoyment (Lawson and Lawson 2013; Meyer and Turner 2002; Shim et al. 2016; Skinner et al. 2008). In contrast, students with a low level of academic engagement are more likely to passively withdraw from learning activities or become bored, anxious, and frustrated with their studies (King et al. 2015; Meyer and Turner 2002; Skinner et al. 2008). Several researchers have described low levels of academic engagement as including exhaustion, lack of interest and lack of regulation of learning (e.g., Nurttila et al. 2015). Engagement in academia is an important predictor of academic achievement and academic performance (Galla et al. 2014; Lee and Shute 2010; Saklofske et al. 2012; Salanova et al. 2010).

Researchers have identified a positive connection between servant leadership and work engagement (van Dierendonck 2011). Based on the COR theory, people always try to acquire and maintain the resources they think are of value. After individual needs are met, people will obtain more resources from their existing resources. After receiving servant supervision, postgraduates will become more focused on and committed to learning and expect to obtain more resources (Hobfoll 1989, 2001). Furthermore, as a motivation level concept, engagement can be explained by the self-determination theory. Johnson and Levy (2008) put forward that at the core of the self-determination theory is the distinction between autonomous and controlled motivation. Autonomy involves acting with a sense of volition and having the experience of volition and choice. Intrinsic motivation is a part of autonomous motivation. When people engage in an activity because they find it interesting, they are doing the activity completely of their own volition, and make statements such as "I like doing academic research." Thus, academic engagement can be considered as intrinsic motivation. From the selfdetermination theory, academic engagement is positively related to employability which 
can be described as "no pain, no gain." Hence, depending on the COR theory and the self-determination theory, we expect the academic engagement of postgraduates to mediate the relationship between servant supervision and employability. Consistent with Hypothesis 2, we propose partial mediation rather than complete mediation.

Hypothesis 3 Postgraduates' academic engagement partially mediates the relationship between servant supervision and employability (Fig. 1).

\section{Methods}

Participants

The participants in this study were 598 young adults enrolled in a wide variety of courses in postgraduate programs from several universities in China. There were 306 young men (51.2\%) and 292 young women (48.8\%), whose mean age was 25 years old $(\mathrm{SD}=2.547)$. The vast majority of students were Chinese, which is typical of universities in China. The participants in this study were drawn from Tsinghua University, Renmin University of China, Beijing Normal University, China Agricultural University, Beijing Institute of Technology, Xi'an Jiaotong University, Southern Medical University and Chinese Academy of Sciences.

In the current postgraduate education system in Chinese universities, masters are divided into research-based masters and professional masters. The academic pressure and requirements of postgraduate students for the research-based master's degree are high. Students need to publish professional, high-quality journal articles, have a solid theoretical foundation, and complete a high-quality degree thesis. For example, in one of the top universities in Chinese mainland, postgraduate students for the research-based master's degree are required to publish two academic articles, as well as one high-quality degree thesis. By contrast, postgraduate students for the degree of professional masters, such as Master of Business Administration (MBA) and Master of Professional Accounting (MPAcc), engage in research work that may not impact their employability as long as they have rich internship experiences. Therefore, postgraduate students for the research-based

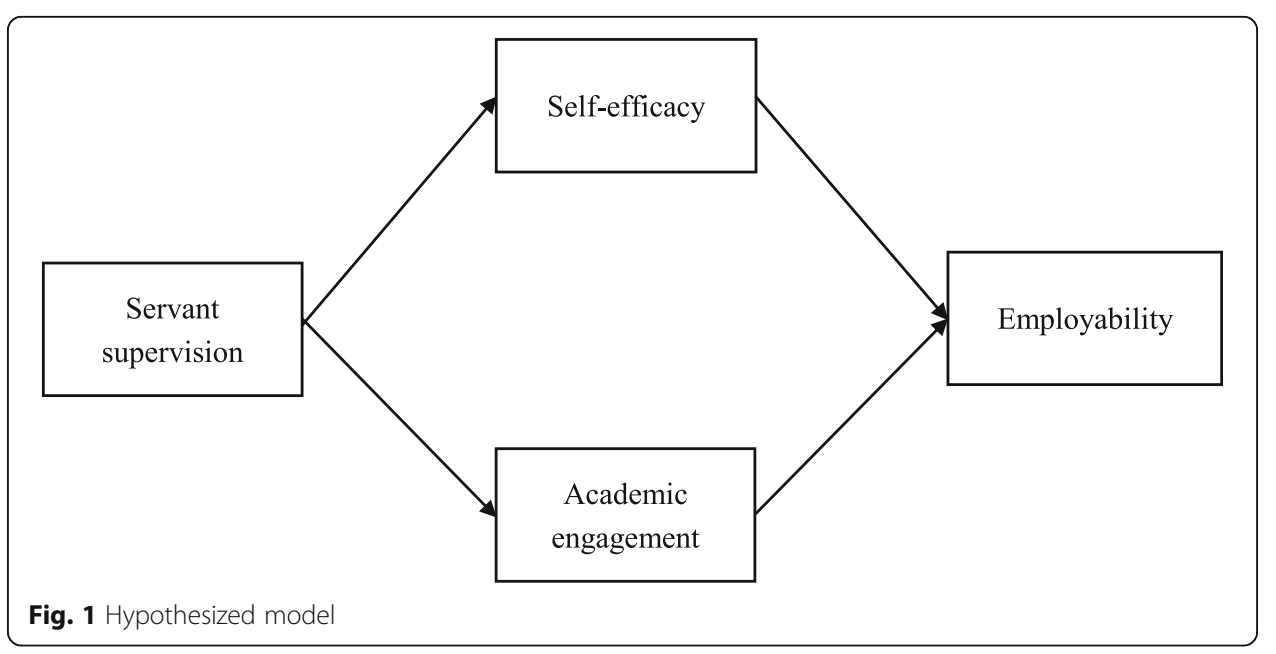


master's degree and $\mathrm{PhD}$ candidates are the selection of samples in this article, referred to as "postgraduates" collectively.

The electronic version of the questionnaire including survey link was emailed to postgraduates from universities outside Beijing, while a paper version of the questionnaire was mailed to postgraduates and returned the same way once they were completed. The response rate for the paper questionnaires in this study was $92 \%$ $(N=614)$. Additionally, the administrators of each of these programs offered a pen with the logo of Renmin University of China as a reward for participating. After six weeks, these reminders ceased, regardless of whether or not an individual completed the survey.

\section{Measures}

We measured all the variables with items already well-established in the existing literature. The Chinese version of the measures was created following the backward translation procedure of Brislin (1980).

\section{Servant leadership}

We used a 28-item scale of servant leadership to assess leader servant supervision $(\alpha=0.90)$ as Liden et al. (2008). We modified the items to apply a referent-shift composition model (Chan 1998), which captures supervision, and identifies who acted as serviceoriented leaders during the academic activities of the participants. The respondents revealed their own agreement with supervisors' behavior based on statements such as "I would seek help from my supervisor if I had a personal problem" and "My supervisor is able to effectively think through complex problems," based on a 5-point scale where $1=$ Strongly Disagree and $5=$ Strongly Agree.

\section{Academic engagement}

We used Skinner et al.'s (2009) 10-item scale for academic engagement (originally a 4-point response format) to assess respondents' academic behavioral engagement and emotional engagement $(\alpha=0.85)$. Students rated their own behavior by considering statements such as "I try hard to do well in school" and "When I'm in class, I listen very carefully" (respectively), in terms of how well each statement described them on a 4-point scale where $1=$ Not At All True and $4=$ Very True.

\section{Self-efficacy}

We used Mencl et al.'s (2012) 17-item scale of self-efficacy to assess the respondents' level of self-efficacy $(\alpha=0.84)$. The students rated their own self-assessment using items such as "When I make plans, I am certain I can make them work" "One of my problems is that I cannot get down to work when I should" based on how much they agreed with each statement on a 5 -point scale where $1=$ Strongly Disagree and $5=$ Strongly Agree.

\section{Employability}

We used Rothwell et al.'s (2009) 3-item scale for employability to assess the respondents' level of employability $(\alpha=0.73)$. The students rated their own employability using statements such as "The skills and abilities that I possess are what employers are 
looking for" "I am generally confident of success in job interviews and selection events" and "I feel I could get any job so long as my skills and experience are reasonably relevant," in terms of how well they agreed with each statement on a 5-point scale where $1=$ Strongly Disagree and $5=$ Strongly Agree .

\section{Control variables}

In addition to the four main variables in our model, we examined a variety of control variables: gender, age, educational status, school category, study degree, and studying time. We found that controlling for these variables (along with other demographics) has no bearing on the results; thus, we excluded them as control variables, following the recommendation of Becker (2005).

\section{Data analyses}

We performed confirmatory factor analysis (CFA) using Mplus 7.11 to test the measurement model. The main purpose of CFA was to test whether servant supervision, academic engagement, employability, and self-efficacy are empirically distinct constructs. Following the suggestion of Little et al. (2002), we created six parcels for servant supervision, three parcels for academic engagement, and three parcels for self-efficacy. The score of an indicator was equal to the average score of the different items according to Jiang (2016). This multidimensional approach for CFA enables the multi-faceted nature of a construct (e.g., career adaptability) to be made empirically explicit. This approach has the ability to alleviate inflated measurement errors that occur when a latent variable has too many items (e.g., 28 items for servant supervision), and can also help reduce bias in the CFA results (Nasser-Abu and Wisenbaker 2006). The results of the CFA are shown in Table 1. Based on the combined evidence of fit indexes (Hu and Bentler 1999), the hypothesized four-factor model fit the data adequately and had a better fit than alternative models. These results suggest that the four measured variables, i.e., servant supervision, academic engagement, employability, and self-efficacy, can be distinguished from one another. Therefore, these variables can legitimately be considered as distinct constructs in subsequent analyses.

Since the four-factor model fit the data better than the one-factor model and all the factor loadings were greater than twice their standard errors as described in previous studies (Anderson and Gerbing 1988), the measurement model was regarded as having adequate convergent validity. As per Harman's test (Podsakoff et al. 2003), the poor fit of the one-factor model also to some extent reduced the concern regarding common method variance (CMV). We also followed Castanheira (2016) to conduct a more rigorous analysis for CMV by adding a latent method factor to the fourfactor model in CFA. The results indicated that the hypothesized four-factor measurement model had a better fit to the data $\left(\chi^{2} / d f=1.76\right.$, SRMR $=0.045, \operatorname{RMSEA}=0.038$, $\mathrm{CFI}=0.894$, TFI $=0.880)$ than the three-factor alternative model $\left(\chi^{2} / d f=1.91\right.$, SRMR $=$ 0.048 , RMSEA $=0.042$, CFI $=0.869$, TFI $=0.854 ; \chi^{2} / d f=2.55$, SRMR $=0.055$, RMSEA $=$ 0.055 , CFI $=0.779$, TFI $=0.754)$, the two-factor alternative model $\left(\chi^{2} / d f=2.93\right.$, SRMR $=$ 0.061 , $\mathrm{RMSEA}=0.062$, CFI $=0.722$, TFI $=0.693$ ), and the one-factor alternative model $\left(\chi^{2} / d f=3.91, \mathrm{SRMR}=0.070, \mathrm{RMSEA}=0.076, \mathrm{CFI}=0.580\right.$, TFI $\left.=0.538\right)$. 
Table 1 Results of confirmatory factor analysis of the study variables

\begin{tabular}{llllllllll}
\hline Model & $\boldsymbol{x}^{\mathbf{2}}$ & $\boldsymbol{d f}$ & $\boldsymbol{\Delta \boldsymbol { x } ^ { 2 }}$ & $\boldsymbol{\Delta d f}$ & CFI & TFI & RMSEA & SRMR \\
\hline 1 & 4-factor: SS, AE, EC, SE & 393.240 & 224 & & & 0.894 & 0.880 & 0.038 & 0.045 \\
2 & 3-factor: SS + AE, EC, SE & 435.642 & 227 & 42.402 & 3 & 0.869 & 0.854 & 0.042 & 0.048 \\
3 & 3-factor: SS, AE, EC + SE & 578.935 & 227 & 185.695 & 3 & 0.779 & 0.754 & 0.055 & 0.055 \\
4 & 2-factor: SS + AE + EC, SE & 671.893 & 229 & 236.251 & 5 & 0.722 & 0.693 & 0.062 & 0.061 \\
5 & 1-factor: SS + AE + EC + SE & 899.216 & 230 & 505.976 & 6 & 0.580 & 0.538 & 0.076 & 0.070 \\
\hline
\end{tabular}

Notes. $N=598$ postgraduates. $X^{2}$ and $\Delta X^{2}$ are significant at $p<0.001$ level

$S S=$ servant supervision, $A E=$ academic engagement, $E C=$ employability, $S E=$ self-efficacy

\section{Results}

\section{Descriptive statistics and correlations}

The means, standard deviations, and correlations of the variables are presented in Table 2. As predicted, academic engagement and self-efficacy are two mediating factors between servant supervision and employability. Servant supervision was found to be positively related to employability.

\section{Testing the hypotheses}

Hypothesis 1 proposed a positive relationship between servant supervision and employability. Regression for the main effect was conducted to simultaneously examine all the indirect relationships. In support of the hypothesis, as shown in Table 3, the results of the regression are presented after controlling for postgraduate gender $(\beta=-0.128$, $p<0.001)$, age $(\beta=0.113, p<0.05)$, educational status $(\beta=0.070$, ns $)$ school category $(\beta=0.004, \mathrm{~ns})$ study degree $(\beta=0.126, p<0.01)$, and study time $(\beta=0.004$, ns). To test the mediation effect, Baron and Kenny's (1986) four conditions for mediation were examined, with further confirmation provided using PROCESS analysis (Hayes 2017) to determine the significance of the indirect effects. Support for the mediation effect requires satisfaction of the following conditions: (1) The predictor significantly relates to the dependent variable; (2) the predictor significantly relates to the mediator; (3) the mediator significantly relates to the dependent variable; and (4) the relationship between the predictor and dependent variable apparently weakens (partial mediation) or becomes insignificant (full mediation) with the addition of the mediator. As presented in Tables 3 and 4, there is a significant relationship between servant supervision and employability (Table 3 Model $4: \beta=0.269, p<0.001$ ) supporting Condition 1 , and thus, Hypothesis 1 was supported. Tables 3 and 4 show that servant supervision is positively related to both self-efficacy and academic engagement (Table 3 Model 2: $\beta=0.259$, $p<0.001$; Table 4 Model 2: $\beta=0.345 p<0.001$ ). Furthermore, both self-efficacy (Table 3 Model 5: $\beta=0.381, p<0.001$ ) and academic engagement (Table 4 Model 5: $\beta=0.464, p<0.001$ ) are positively related to employability. Conditions 2 and 3 were supported. In addition, when the predictor, self-efficacy and academic engagement were simultaneously added into the regression equation, the relationship between servant supervision and employability apparently weakened, as the regression coefficient decreased from $\beta=0.269, p<0.001$ (Table 3 Model 4) to $\beta=0.183, p<0.001$ (Table 3 Model 6) as well as from $\beta=0.269, p<0.001$ (Table 4 Model 4) to $\beta=0.124, p<0.001$ (Table 4 Model 6). Thus, Condition 4 was satisfied. With the presence of self-efficacy 


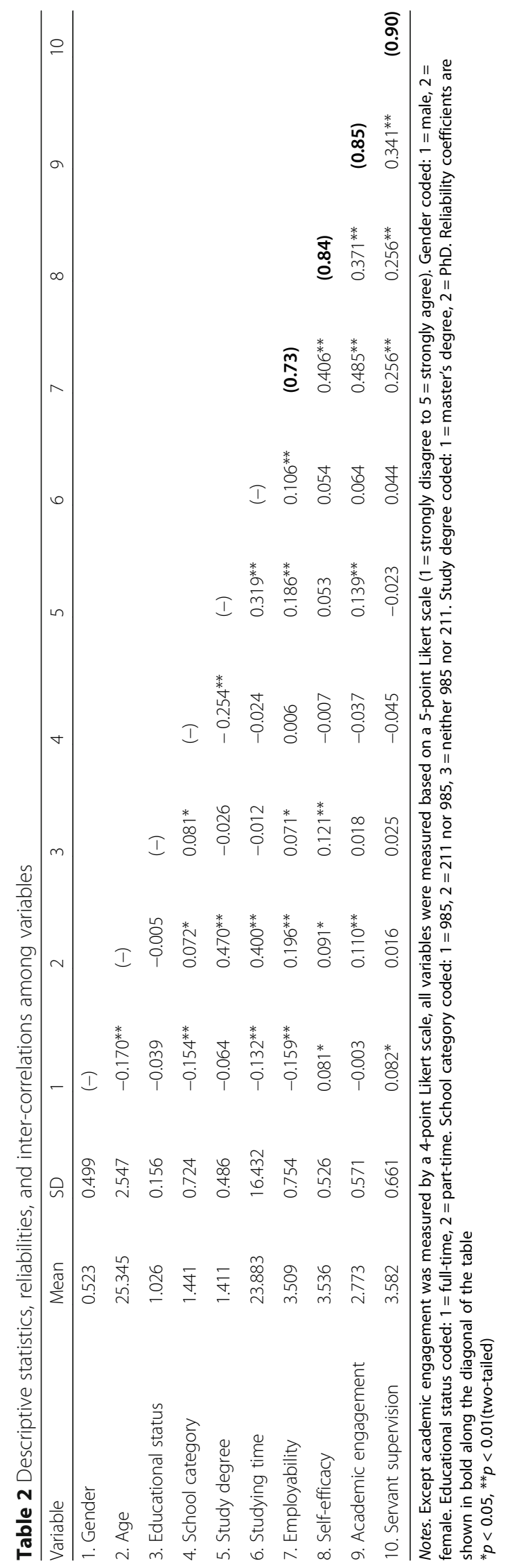


Table 3 Regression results for the mediating effect of self-efficacy

\begin{tabular}{|c|c|c|c|c|c|c|}
\hline & \multicolumn{2}{|c|}{ Self-efficacy } & \multicolumn{4}{|c|}{ Employability } \\
\hline & Model 1 & Model 2 & Model 3 & Model 4 & Model 5 & Model 6 \\
\hline \multicolumn{7}{|l|}{ Step 1} \\
\hline Gender & -0.066 & $-0.088^{*}$ & $-0.128^{* *}$ & $-0.151^{* * *}$ & $-0.102^{* *}$ & $-0.121^{* *}$ \\
\hline Age & 0.074 & 0.063 & $0.113^{*}$ & $0.102^{*}$ & 0.085 & 0.081 \\
\hline Educational status & $0.121^{* *}$ & $0.113^{* *}$ & 0.07 & 0.061 & 0.024 & 0.024 \\
\hline School category & -0.031 & -0.017 & 0.004 & 0.019 & 0.016 & 0.025 \\
\hline Study degree & 0.004 & 0.022 & $0.126^{* *}$ & $0.144^{* *}$ & $0.124^{* *}$ & $0.137^{* *}$ \\
\hline Studying time & 0.015 & 000 & 0.004 & -0.011 & -0.001 & -0.011 \\
\hline \multicolumn{7}{|l|}{ Step 2} \\
\hline Servant supervision & & $0.259^{* * *}$ & & $0.269^{* * *}$ & & $0.183^{* * *}$ \\
\hline \multicolumn{7}{|l|}{ Step 3} \\
\hline Self-efficacy & & & & & $0.381^{* * *}$ & $0.332^{* * *}$ \\
\hline$R^{2}$ & 0.028 & 0.094 & 0.071 & 0.143 & 0.212 & 0.243 \\
\hline$\Delta R^{2}$ & 0.028 & 0.066 & 0.071 & 0.072 & 0.031 & 0.212 \\
\hline
\end{tabular}

Notes. $N=598 .{ }^{*} p<0.05,{ }^{* *} p<0.01,{ }^{* * *} p<0.001$

and academic engagement, the relationship between servant supervision and employability became insignificant (Table 5 Model 4: $\beta=0.090, p<0.05$ ), indicating a partial mediation effect. The above results provided initial support for the mediating roles of self-efficacy and academic engagement in the servant supervision-employability relationship as put forward in Hypotheses 2 and 3.

To further directly examine the proposed mediation effect, we performed bootstrapping procedures using PROCESS simulation techniques (Hayes 2017). As shown in Table 6, with 5,000 replications, we found that the indirect effect of servant supervision on employability through self-efficacy was 0.098 , with a $95 \%$ bias-corrected bootstrap

Table 4 Regression results for the mediating effect of academic engagement

\begin{tabular}{|c|c|c|c|c|c|c|}
\hline & \multicolumn{2}{|c|}{ Academic engagement } & \multicolumn{4}{|c|}{ Employability } \\
\hline & Model 1 & Model 2 & Model 3 & Model 4 & Model 5 & Model 6 \\
\hline \multicolumn{7}{|l|}{ Step 1} \\
\hline Gender & 0.013 & -0.016 & $-0.128^{* *}$ & $-0.151^{* * *}$ & $-0.134^{* * *}$ & $-0.144^{* * *}$ \\
\hline Age & 0.061 & 0.046 & $0.113^{*}$ & $0.102^{*}$ & $0.085^{*}$ & 0.082 \\
\hline Educational status & 0.023 & 0.012 & 0.070 & 0.061 & 0.059 & 0.056 \\
\hline School category & -0.014 & 0.005 & 0.004 & 0.019 & 0.011 & 0.017 \\
\hline Study degree & 0.105 & $0.129^{* *}$ & $0.126^{* *}$ & $0.144^{* *}$ & 0.077 & 0.090 \\
\hline Studying time & 0.008 & -0.012 & 0.004 & -0.011 & 0.001 & -0.006 \\
\hline \multicolumn{7}{|l|}{ Step 2} \\
\hline Servant supervision & & $0.345^{* * *}$ & & $0.269^{* * *}$ & & $0.124^{* * *}$ \\
\hline \multicolumn{7}{|l|}{ Step 3} \\
\hline Academic engagement & & & & & $0.464^{* * *}$ & $0.420^{* * *}$ \\
\hline$R^{2}$ & 0.023 & 0.140 & 0.071 & 0.143 & 0.281 & 0.295 \\
\hline$\Delta R^{2}$ & 0.023 & 0.117 & 0.071 & 0.072 & 0.014 & 0.281 \\
\hline
\end{tabular}

Notes. $N=598 .{ }^{*} p<0.05,{ }^{* *} p<0.01,{ }^{* * *} p<0.001$ 
confidence interval of $[0.061,0.143]$, which does not contain zero. Thus, the mediating effect of self-efficacy on employability proposed in Hypothesis 2 was supported. Furthermore, the 5,000 replications showed that the indirect effect of academic engagement on employability was 0.165 , with a $95 \%$ bias-corrected bootstrap confidence interval of $[0.122,0.218]$, again not containing zero, and thus providing support for $\mathrm{Hy}-$ pothesis 3. The results of PROCESS provide support for all hypotheses (Fig. 2).

\section{Discussion}

Our study is among the first to examine the effects of supervisors' servant behavior on postgraduates' employability in the educational field. Based on the COR, our study demonstrates whether and how servant supervision influences postgraduates' employability. Specifically, both postgraduate self-efficacy and academic engagement were found to serve as mediators that account for the effect of the servant supervision on postgraduates' employability. Our findings have important theoretical and managerial implications.

\section{Theoretical implications}

This study contributes to the literature on servant supervision in several ways. First, our research uses a service perspective to examine the role of servant supervision on shaping the future employability of postgraduates. Although prior studies have found that servant leadership is significantly related to voice behavior, creativity, and OCB (e.g., Chen et al. 2015; Yang et al. 2017), investigations of its effect on postgraduates' employability are surprisingly scarce. Our findings provide further support for the view of the relevance of servant leadership on student employability. Future research can

Table 5 Regression results for the mediating effect of self-efficacy and academic engagement

\begin{tabular}{|c|c|c|c|c|}
\hline & \multicolumn{4}{|c|}{ Employability } \\
\hline & Model 1 & Model 2 & Model 3 & Model 4 \\
\hline \multicolumn{5}{|l|}{ Step 1} \\
\hline Gender & $-0.128^{* *}$ & $-0.151^{* * *}$ & $-0.121^{* *}$ & $-0.125^{* * *}$ \\
\hline Age & $0.113^{*}$ & $0.102^{*}$ & 0.081 & 0.071 \\
\hline Educational status & 0.070 & 0.061 & 0.024 & 0.031 \\
\hline School category & 0.004 & 0.019 & 0.025 & 0.021 \\
\hline Study degree & 0.126 & $0.144^{* *}$ & 0.137 & $0.094^{*}$ \\
\hline Studying time & 0.004 & -0.011 & -0.011 & -0.007 \\
\hline \multicolumn{5}{|l|}{ Step 2} \\
\hline Servant supervision & & $0.269^{* * *}$ & $0.183^{* * *}$ & $0.090^{*}$ \\
\hline \multicolumn{5}{|l|}{ Step 3} \\
\hline Self-efficacy & & & $0.332^{* * *}$ & $0.229^{* * *}$ \\
\hline Academic engagement & & & & $0.349^{* * *}$ \\
\hline$R^{2}$ & 0.071 & 0.143 & 0.243 & 0.338 \\
\hline$\Delta R^{2}$ & 0.071 & 0.072 & 0.161 & 0.167 \\
\hline
\end{tabular}

Notes. $N=598 .{ }^{*} p<0.05,{ }^{* *} p<0.01,{ }^{* * *} p<0.001$ 
Table 6 Bootstrapping results for testing the mediating effect of self-efficacy and academic engagement

\begin{tabular}{llll}
\hline & $\begin{array}{l}\text { Indirect } \\
\text { effect } b\end{array}$ & $\begin{array}{l}\text { Bootstrapped } \\
t \text { standard error }\end{array}$ & $\begin{array}{l}\text { Indirect effects } \\
\text { (bias corrected } \\
\text { and accelerated } \\
95 \% \text { confidence } \\
\text { interval) }\end{array}$ \\
\hline $\begin{array}{l}\text { 1 Servant supervision } \rightarrow \text { Self-efficacy } \rightarrow \text { Employability } \\
\text { Servant supervision } \rightarrow \text { Academic engagement } \rightarrow \text { Employability }\end{array}$ & 0.098 & 0.208 & {$[0.0610 .143]$} \\
\hline
\end{tabular}

Notes. $N=598$. Intercepts were allowed to vary across supervisory units. All variables were measured at the individual follower level (Level 1) of analysis. The 95\% confidence intervals for the conditional indirect effects, the conditional direct effects were calculated using PROCESS bootstrapping with 5000 replications. The $95 \%$ bias corrected bootstrapped confidence interval does not include zero; $p<0.05$ (single-tailed)

adopt a service perspective to examine other possible antecedents of employability at work.

Second, while the majority of previous studies on servant leadership have relied on theoretical perspectives such as social exchange theory (e.g., Liden et al. 2008; Liden et al. 2014) and social identity theory (e.g., Chen et al. 2015; Liden et al. 2014) to explain the effect of servant leadership on employee behavior, we have integrated the COR and selfdetermination to examine two theoretically plausible explanations for the effects of servant supervision on postgraduates' employability. Specifically, our study sheds light on the dualregulation mechanisms of servant supervision by demonstrating that postgraduates pursue individual resources (e.g., employability) not only out of the desire to enhance their individual cognitive abilities (i.e., self-efficacy), but also because they reconstruct their selfmotivation (i.e., academic engagement) and explicitly symbolize their employability through servant supervision. This finding corroborates the original theoretical conceptualization of servant leadership (Liden et al. 2008; Liden et al. 2014; van Dierendonck and Nuijten 2011), which describes a servant leader as both a service-oriented manager who actively provides help and support to his or her followers and a moral person who transforms the selfconcept of postgraduates via role modeling behavior that manifests his or her service beliefs. In short, our study provides a more complete account of how the service-oriented manager and moral person dimensions concurrently exert significant influence on postgraduates'

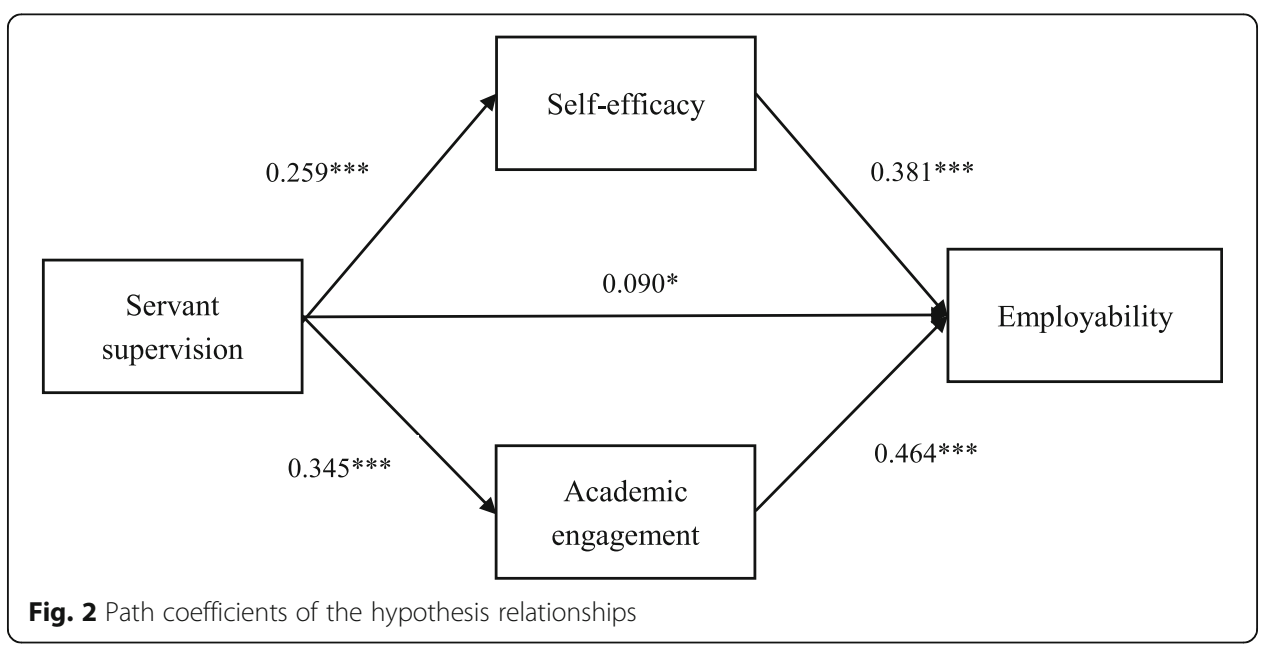


abilities. In doing so, we provide empirical evidence that confirms the theoretical conceptualization of servant supervision, in which we underscore the equal importance of a leader being both a service-oriented supervisor and a moral person to enhance the individual resources of postgraduates (i.e., employability).

Third, our results indicate that postgraduates' self-efficacy and academic engagement are equally important for postgraduates' employability. This result further reinforces the long-held notion of servant supervision as a service-oriented leadership style (Liden et al. 2014). By being a genuine service role model, a servant supervisor's values are identified and symbolized by postgraduates. Moreover, our findings show that selfefficacy and academic engagement are associated with a level of explanatory power similar to role setting in the relationship between servant supervision and employability. In short, our findings to a large extent provide support for the effectiveness of the dual mechanisms implied by the servant supervision concept in shaping postgraduates' abilities and resources. Our theoretical model connects leadership, self-cognition, employability, and motivation literature in a meaningful way and highlights the importance of future research for interpreting the implications of servant leadership in light of its internal and external influence on individuals' self-cognition and motivation.

\section{Practical implications}

Our study provides valuable insights into how supervisors might promote their postgraduates' employability. First, our study shows that service-orientation supervisors play an active role in enhancing employability among postgraduates. To do so, supervisors may want to participate in assistant programs to promote service behavior and practice serving as a role model to motivate postgraduates to behave in a way that takes others' interests into consideration. Given the importance of servant supervision in increasing employability, universities might cultivate servant supervision by offering training programs to supervisors, emphasizing the importance of ethical principles, and providing examples of servant conduct that supervisors should manifest in their daily behavior and management policies. Moreover, managers should be aware that external regulation is sometimes just as important as internal regulation in driving employability in universities. Therefore, supervisors should pay more attention to their servant behavior to help and improve their postgraduates' employability.

\section{Limitations and future research}

There are also some limitations. First, in the present research, we focused on academic engagement as a driving force in shaping postgraduates' employability. We do not know if other types of motivation in the self-determination paradigm might play similar roles in our proposed relationships. In addition, our results demonstrate that the effect sizes of the hypothesized relationships among servant supervision, postgraduates' selfefficacy, academic engagement and postgraduates' employability are moderate, indicating that there might be other factors that account for the variance in postgraduates' employability. Another limitation of this study is that it incorporates a cross-sectional design, which limits our ability to make strong causal inferences among the variables in the theoretical model. Maxwell stressed that cross-sectional data may be biased because they fail to address the autoregressive effects of mediators on dependent variables 
(Maxwell and Cole 2007). This practice of data collection is widely used in research focused on the supervisor and postgraduate interface because collecting data from multiple sources on this sensitive topic is challenging. However, in this study the following factors may have attenuated the possibility of common method bias (Podsakoff et al. 2003): (1) using different scale formats (i.e., 4- and 5-point scales); and (2) as the confirmatory factor analyses revealed, the variables were distinct constructs. Item overlap was very limited. Furthermore, common method bias cannot explain the significant moderating effect of self-efficacy (Evans 1985). Nonetheless, subsequent research should replicate our theoretical model with multi-source datasets.

Finally, we presented a dual meditational process of self-efficacy and academic engagement, but our same-level research design is not an ideal approach to test such a causal process model. Therefore, future research needs to employ a longitudinal research design to better test the dual meditational model. Perhaps a second survey could be conducted to test the same dual meditational model in order to strengthen its reliability and variability. Furthermore, in this research, the conditional effect was not considered. Moderators could further explain how and in what conditions servant supervision has a positive or negative effect on employability. In future research, context factors, such as traditionality, power distance, or psychological contract fulfillment could be examined.

Acknowledgements

Not applicable.

\section{Authors' contributions}

All authors contributed significantly to the manuscript. All authors read and approved the final manuscript.

Authors' information

Lifeng Zhong (Ph.D., University of Chinese Academy of Sciences) is an associate professor in Business School, Renmin University of China. His research interests are leadership human resource management, and employee well-being. His research appears in Journal of Organizational Behavior, Leadership Quarterly, Management World, Psychological Bulletin, and Advances in Psychological Science.

Zhichao Qian is a Ph.D. candidate in Business School, Renmin University of China. Her research interests are servant leadership, employee well-being. Her research appears in Science of Science and Management of S\&T.

Dongdong Wang (Ph.D., Renmin University of China) is a lecturer in School of Business Administration, Nanjing University of Finance and Economics. His research interests are human resource management and innovation. His research appears in Management Review, Chinese Journal of Management, Journal of Industrial Engineering and Engineering Management, Science of Science and Management of S\&T, and Economist.

\section{Funding}

This research is supported by a grant from the National Natural Science Foundation of China (Contract/Grant Number: 71672190).

\section{Availability of data and materials}

The data sets used and/or analyzed during the current study are available from the corresponding author on reasonable request.

Competing interests

The authors declare that they have no competing interests.

\section{Author details}

${ }^{1}$ Business School, Renmin University of China, Beijing 100872, China. ${ }^{2}$ Nanjing University of Finance \& Economics, Nanjing 210046, Jiangsu Province, China.

Received: 27 September 2019 Accepted: 31 March 2020

Published online: 15 May 2020

\section{References}

Acikgoz, Y., Sumer, H. C., \& Sumer, N. (2016). Do employees leave just because they can? Examining the perceived employability-turnover intentions relationship. The Journal of Psychology, 150(5), 666-683.

Anderson, J. C., \& Gerbing, D. W. (1988). Structural equation modeling in practice: a review and recommended two-step approach. Psychological Bulletin, 103(3), 411-423. 
Appleton, J. J., Christenson, S. L., \& Furlong, M. J. (2008). Student engagement with school: critical conceptual and methodological issues of the construct. Psychology in the Schools, 45(5), 369-386.

Bandura, A. (1997). Self-efficacy: The exercise of control. New York: Freeman.

Barbuto Jr., J. E., \& Wheeler, D. W. (2006). Scale development and construct clarification of servant leadership. Group \& Organization Management, 31(3), 300-326.

Baron, R. M., \& Kenny, D. A. (1986). The moderator-mediator variable distinction in social psychological research: conceptual, strategic, and statistical considerations. Journal of Personality and Social Psychology, 51(6), 1173-1182.

Becker, T. E. (2005). Potential problems in the statistical control of variables in organizational research: a qualitative analysis with recommendations. Organizational Research Methods, 8(3), 274-289.

Berntson, E., \& Marklund, S. (2007). The relationship between perceived employability and subsequent health. Work and Stress, 21(3), 279-292.

Brislin, R. W. (1980). Translation and content analysis of oral and written material. In H. C. Triandis \& J. W. Berry (Eds.), Handbook of crosscultural psychology (Vol. 2, pp. 389-444). Boston: Allyn \& Bacon.

Brummelhuis, L. L., \& Trougakos, J. P. (2014). The recovery potential of intrinsically versus extrinsically motivated off-job activities. Journal of Occupational and Organizational Psychology, 87(1), 177-199.

Castanheira, F. (2016). Perceived social impact, social worth, and job performance: mediation by motivation. Journal of Organizational Behavior, 37(6), 789-803.

Chan, D. (1998). Functional relations among constructs in the same content domain at different levels of analysis: a typology of composition models. Journal of Applied Psychology, 83(2), 234-246.

Chemers, M. M., Hu, L., \& Garcia, B. F. (2001). Academic self-efficacy and first-year college student performance and adjustment. Journal of Educational Psychology, 93(1), 55-64.

Chen, G., \& Bliese, P. D. (2002). The role of different levels of leadership in predicting self- and collective efficacy: evidence for discontinuity. Journal of Applied Psychology, 87(3), 549-556.

Chen, Z., Zhu, J., \& Zhou, M. (2015). How does a servant leader fuel the service fire? A multilevel model of servant leadership, individual self-identity, group competition climate, and customer service performance. Journal of Applied Psychology, 100(2), 511-521.

Chiniara, M., \& Bentein, K. (2016). Linking servant leadership to individual performance: differentiating the mediating role of autonomy, competence and relatedness need satisfaction. The Leadership Quarterly, 27(1), 124-141.

Chiniara, M., \& Bentein, K. (2018). The servant leadership advantage: when perceiving low differentiation in leader-member relationship quality influences team cohesion, team task performance and service OCB. The Leadership Quarterly, 29(2), 333-345.

Creed, P. A., Hood, M., \& Hu, S. (2017). Personal orientation as an antecedent to career stress and employability confidence: the intervening roles of career goal-performance discrepancy and career goal importance. Journal of Vocational Behavior, 99, 79-92.

de Cuyper, N., Mauno, S., Kinnunen, U., \& Mäkikangas, A. (2011). The role of job resources in the relation between perceived employability and turnover intention: a prospective two-sample study. Journal of Vocational Behavior, 78(2), $253-263$.

Dennis, R. S., \& Bocarnea, M. (2005). Development of the servant leadership assessment instrument. Leadership and Organization Development Journal, 26, 600-615.

Ehrhart, M. G. (2004). Leadership and procedural justice climate as antecedents of unit-level organizational citizenship behavior. Personnel Psychology, 57(1), 61-94.

Evans, M. G. (1985). A Monte Carlo study of the effects of correlated method variance in moderated multiple regression analysis. Organizational Behavior and Human Decision Processes, 36, 305-323.

Forrier, A., \& Sels, L. (2003). The concept employability: a complex mosaic. International Journal of Human Resources Development and Management, 3, 102-124.

Forrier, A., Verbruggen, M., \& De Cuyper, N. (2015). Integrating different notions of employability in a dynamic chain: the relationship between job transitions, movement capital and perceived employability. Journal of Vocational Behavior, 89 , $56-64$.

Fredricks, J. A., Blumenfeld, P. C., \& Paris, A. H. (2004). School engagement: potential of the concept, state of the evidence. Review of Educational Research, 74(1), 59-109.

Fugate, M., Kinicki, A. J., \& Ashforth, B. E. (2004). Employability: a psycho-social construct, its dimensions, and applications. Journal of Vocational Behavior, 65(1), 14-38.

Galla, B. M., Wood, J. J., Tsukayama, E., Har, K., Chiu, A. W., \& Langer, D. A. (2014). A longitudinal multilevel model analysis of the within-person and between-person effect of effortful engagement and academic self-efficacy on academic performance. Journal of School Psychology, 52(3), 295-308.

Greenleaf, R. K. (1970). The servant as leader. Newton Centre: Robert K. Greenleaf Center

Hayes, A. F. (2017). Introduction to mediation, moderation, and conditional process analysis: a regression-based approach. New York: Guilford Publications.

Hillage, J., \& Pollard, E. (1998). Employability: developing a framework for policy analysis (Vol. 107). London: Department for Education and Employment.

Hobfoll, S. E. (1989). Conservation of resources: a new attempt at conceptualizing stress. American Psychologist, 44(3), 513-524.

Hobfoll, S. E. (2001). The influence of culture, community, and the nested-self in the stress process: advancing conservation of resources theory. Journal of Applied Psychology, 50(3), 337-421.

Hu, J., \& Liden, R. C. (2011). Antecedents of team potency and team effectiveness: an examination of goal and process clarity and servant leadership. Journal of Applied Psychology, 96(4), 851-862.

Hu, L. T., \& Bentler, P. M. (1999). Cutoff criteria for fit indexes in covariance structure analysis: conventional criteria versus new alternatives. Structural Equation Modeling: A Multidisciplinary Journal, 6(1), 1-55.

Hunter, E. M., Neubert, M. J., Perry, S. J., Witt, L. A., Penney, L. M., \& Weinberger, E. (2013). Servant leaders inspire servant followers: antecedents and outcomes for employees and the organization. The Leadership Quarterly, 24(2), $316-331$.

Jiang, Z. (2016). The relationship between career adaptability and job content plateau: the mediating roles of fit perceptions. Journal of Vocational Behavior, 95, 1-10. 
Johnson, R. E., \& Levy, R. P. E. (2008). Getting to the core of core self-evaluation: a review and recommendations. Journal of Organizational Behavior, 29(3), 391-413.

King, R. B., Mcinerney, D. M., Ganotice, F. A., \& Villarosa, J. B. (2015). Positive affect catalyzes academic engagement: crosssectional, longitudinal, and experimental evidence. Learning and Individual Differences, 39, 64-72.

Kirschenbaum, A., \& Mano-Negrin, R. (1999). Underlying labor market dimensions of "opportunities": The case of employee turnover. Human Relations, 52(10), 1233-1255.

Kirves, K., Kinnunen, U., De Cuyper, N., \& Mäkikangas, A. (2014). Trajectories of perceived employability and their associations with well-being at work. Journal of Personnel Psychology, 13(1), 46-57.

Lawson, M. A., \& Lawson, H. A. (2013). New conceptual frameworks for student engagement research, policy, and practice. Review of Educational Research, 83(3), 432-479.

Lee, J., \& Shute, V. J. (2010). Personal and social-contextual factors in K-12 academic performance: an integrative perspective on student learning. Educational Psychologist, 45(3), 185-202.

Liden, R. C., Wayne, S. J., Liao, C., \& Meuser, J. D. (2014). Servant leadership and serving culture: influence on individual and unit performance. Academy of Management Journal, 57(5), 1434-1452.

Liden, R. C., Wayne, S. J., Zhao, H., \& Henderson, D. (2008). Servant leadership: development of a multidimensional measure and multi-level assessment. The Leadership Quarterly, 19(2), 161-177.

Little, T. D., Cunningham, W. A., Shahar, G., \& Widaman, K. F. (2002). To parcel or not to parcel: exploring the question, weighing the merits. Structural Equation Modeling, 9(2), 151-173.

Lu, C. Q., Sun, J. W., \& Du, D. Y. (2016). The relationships between employability, emotional exhaustion, and turnover intention: the moderation of perceived career opportunity. Journal of Career Development, 43(1), 37-51.

Lysova, E. I., Jansen, P. G., Khapova, S. N., Plomp, J., \& Tims, M. (2018). Examining calling as a double-edged sword for employability. Journal of Vocational Behavior, 104, 261-272.

Maxwell, S. E, \& Cole, D. A. (2007). Bias in cross-sectional analyses of longitudinal mediation. Psychological Methods, 12(1), 23-44.

Mayer, D. M. (2010). Servant leadership and follower need satisfaction: Where Do We Go from Here? In D. van Dierendonck \& K. Patterson (Eds.), Servant Leadership (pp. 147-154). London: Palgrave Macmillan.

McArdle, S., Waters, L., Briscoe, J. P., \& Hall, D. T. T. (2007). Employability during unemployment: adaptability, career identity and human and social capital. Journal of Vocational Behavior, 71(2), 247-264.

Mencl, J., Tay, L., Schwoerer, C. E., \& Drasgow, F. (2012). Evaluating quantitative and qualitative types of change: an analysis of the malleability of general and specific self-efficacy constructs and measures. Journal of Leadership and Organizational Studies, 19(3), 378-391.

Meyer, D. K., \& Turner, J. C. (2002). Discovering emotion in classroom motivation research. Educational Psychologist, 37(2), 107-114.

Nasser-Abu Alhija, F., \& Wisenbaker, J. (2006). A Monte Carlo study investigating the impact of item parceling strategies on parameter estimates and their standard errors in CFA. Structural Equation Modeling, 13(2), 204-228.

Nelissen, J., Forrier, A., \& Verbruggen, M. (2017). Employee development and voluntary turnover: testing the employability paradox. Human Resource Management Journal, 27(1), 152-168.

Neubert, M. J., Hunter, E. M., \& Tolentino, R. C. (2016). A servant leader and their stakeholders: when does organizational structure enhance a leader's influence? The Leadership Quarterly, 27(6), 896-910.

Neubert, M. J., Kacmar, K. M., Carlson, D. S., Chonko, L. B., \& Roberts, J. A. (2008). Regulatory focus as a mediator of the influence of initiating structure and servant leadership on employee behavior. Journal of Applied Psychology, 93(6), 1220-1233.

Nurttila, S., Ketonen, E., \& Lonka, K. (2015). Sense of competence and optimism as resources to promote academic engagement. Procedia-Social and Behavioral Sciences, 171, 1017-1026.

Peterson, S. J., Galvin, B. M., \& Lange, D. (2012). CEO servant leadership: exploring executive characteristics and firm performance. Personnel Psychology, 65(3), 565-596.

Pinto, L. H., \& Ramalheira, D. C. (2017). Perceived employability of business graduates: the effect of academic performance and extracurricular activities. Journal of Vocational Behavior, 99, 165-178.

Podsakoff, P. M., MacKenzie, S. B., Lee, J. Y., \& Podsakoff, N. P. (2003). Common method biases in behavioral research: a critical review of the literature and recommended remedies. Journal of Applied Psychology, 88(5), 879-903.

Rajan, A. (1997). Employability in the finance sector: rhetoric vs reality. Human Resource Management Journal, 7(1), 67-78.

Rothwell, A., \& Arnold, J. (2007). Self-perceived employability: development and validation of a scale. Personnel Review, 36(1), $23-41$.

Rothwell, A., Jewell, S., \& Hardie, M. (2009). Self-perceived employability: investigating the responses of post-graduate students. Journal of Vocational Behavior, 75(2), 152-161.

Saklofske, D. H., Austin, E. J., Mastoras, S. M., Beaton, L., \& Osborne, S. E. (2012). Relationships of personality, affect, emotional intelligence and coping with student stress and academic success: different patterns of association for stress and success. Learning and Individual Differences, 22(2), 251-257.

Salanova, M., Schaufeli, W., Martínez, I., \& Bresó, E. (2010). How obstacles and facilitators predict academic performance: the mediating role of study burnout and engagement. Anxiety, Stress, and Coping, 23(1), 53-70.

Schaubroeck, J., Lam, S. S., \& Peng, A. C. (2011). Cognition-based and affect-based trust as mediators of leader behavior influences on team performance. Journal of Applied Psychology, 96(4), 863-871.

Schneider, S. K., \& George, W. M. (2011). Servant leadership versus transformational leadership in voluntary service organizations. Leadership and Organization Development Journal, 32, 60-77.

Schwarz, G., Newman, A., Cooper, B., \& Eva, N. (2016). Servant leadership and follower job performance: the mediating effect of public service motivation. Public Administration, 94(4), 1025-1041.

Sendjaya, S., Sarros, J. C., \& Santora, J. C. (2008). Defining and measuring servant leadership behavior in organizations. Journal of Management Studies, 45(2), 402-424.

Shim, S. S., Rubenstein, L. D., \& Drapeau, C. W. (2016). When perfectionism is coupled with low achievement: the effects on academic engagement and help seeking in middle school. Learning and Individual Differences, 45, 237-244.

Skinner, E., Furrer, C., Marchand, G., \& Kindermann, T. (2008). Engagement and disaffection in the classroom: part of a larger motivational dynamic? Journal of Educational Psychology, 100(4), 765-781.

Skinner, E. A., Kindermann, T. A., \& Furrer, C. J. (2009). A motivational perspective on engagement and disaffection: conceptualization and assessment of children's behavioral and emotional participation in academic activities in the classroom. Educational and Psychological Measurement, 69(3), 493-525. 
van der Heijde, C. M., \& van der Heijden, B. I. (2006). A competence-based and multidimensional operationalization and measurement of employability. Human Resource Management, 45(3), 449-476.

Van Dierendonck, D. (2011). Servant leadership: A review and synthesis. Journal of Management, 37(4), 1228-1261.

van der Heijden, B. I., \& Bakker, A. B. (2011). Toward a mediation model of employability enhancement: a study of employeesupervisor pairs in the building sector. The Career Development Quarterly, 59(3), 232-248.

van Dierendonck, D., \& Nuijten, I. (2011). The servant leadership survey: development and validation of a multidimensional measure. Journal of Business and Psychology, 26(3), 249-267.

Vanhercke, D., Cuyper, N. D., Peeters, E., \& Witte, H. D. (2014). Defining perceived employability: a psychological approach. Personnel Review, 43(4), 592-605.

Walumbwa, F. O., Hartnell, C. A., \& Oke, A. (2010). Servant leadership, procedural justice climate, service climate, employee attitudes, and organizational citizenship behavior: a cross-level investigation. Journal of Applied Psychology, 95(3), 517-529.

Wang, M., Kwan, H. K., \& Zhou, A. (2017). Effects of servant leadership on work-family balance in China. Asia-Pacific Journal of Human Resources, 55, 387-407.

Wang, Z., Xu, S., Sun, Y., \& Liu, Y. (2019). Transformational leadership and employee voice: an affective perspective. Frontiers of Business Research in China, 13(1), 19-32.

Wubbels, T., Brekelmans, M., Den Brok, P., \& Van Tartwijk, J. (2006). An interpersonal perspective on classroom management in secondary classrooms in the Netherlands. In C. Evertson \& C. Weinstein (Eds.), Handbook of Classroom Management: Research Practice and Contemporary Issues (pp. 1161-1191). New York: Lawrence Erlbaum Associates.

Yang, J., Liu, H., \& Gu, J. (2017). A multi-level study of servant leadership on creativity. Leadership and Organization Development Journal, 38(5), 610-629.

Yang, Z., Zhang, H., Kwan, H. K., \& Chen, S. (2018). Crossover effects of servant leadership and job social support on employee spouses: the mediating role of employee organization-based self-esteem. Journal of Business Ethics, 147(3), 595-604.

Yoshida, D. T., Sendjaya, S., Hirst, G., \& Cooper, B. (2014). Does servant leadership foster creativity and innovation? A multilevel mediation study of identification and prototypicality. Journal of Business Research, 67(7), 1395-1404.

Zhang, H., Kwong Kwan, H., Everett, A. M., \& Jian, Z. (2012). Servant leadership, organizational identification, and work-tofamily enrichment: the moderating role of work climate for sharing family concerns. Human Resource Management, 51(5), 747-767.

Zou, W. C., Tian, Q., \& Liu, J. (2015). Servant leadership, social exchange relationships, and follower's helping behavior: positive reciprocity belief matters. International Journal of Hospitality Management, 51, 147-156.

\section{Publisher's Note}

Springer Nature remains neutral with regard to jurisdictional claims in published maps and institutional affiliations.

\section{Submit your manuscript to a SpringerOpen ${ }^{\circ}$ journal and benefit from:}

- Convenient online submission

- Rigorous peer review

Open access: articles freely available online

High visibility within the field

- Retaining the copyright to your article

Submit your next manuscript at $\boldsymbol{\nabla}$ springeropen.com 